\title{
Erratum to: The PNPLA3 lle148Met interacts with overweight and dietary intakes on fasting triglyceride levels
}

Ivana A. Stojkovic ${ }^{1}$, Ulrika Ericson ${ }^{1}$, Gull Rukh ${ }^{1}$, Martin Ridderstråle ${ }^{2,3}$, Stefano Romeo ${ }^{4}$ and Marju Orho-Melander ${ }^{1,5^{*}}$

\section{Erratum}

The author name Martin Ridderstråle was incorrectly spelt as Martin Riddestråle during the production of the original article [1]. This has now been corrected in the above author list and the publisher apologises for any inconvenience caused.

\section{Author details \\ ${ }^{1} T$ The Clinical Nutrition Unit, Department of Clinical Sciences in Malmö, Diabetes and Cardiovascular Disease, Genetic Epidemiology, Lund University, Lund, Sweden. ${ }^{2}$ Department of Clinical Sciences, Clinical Obesity Research, Lund University, Skåne University Hospital Malmö, Malmö, Sweden. ${ }^{3}$ Steno Diabetes Center, Gentofte, Danmark. ${ }^{4}$ Department of Molecular and Clinical Medicine, Sahlgrenska Center for Cardiovascular and Metabolic Research, University of Gothenburg, Göteborg, Sweden. ${ }^{5} \mathrm{Clinical}$ Research Centre, Building 91:12, SUS in Malmö, Jan Waldenströms gata 35, 20502 Malmö, Sweden.}

Published online: 25 April 2016

\section{Reference}

1. Stojkovic IA, Ericson U, Rukh G, Ridderstråle M, Romeo S, Orho-Melander M. The PNPLA3 lle148Met interacts with overweight and dietary intakes on fasting triglyceride levels. Genes Nutr. 2014;9:388.

\footnotetext{
* Correspondence: marju.orho-melander@med.lu.se

${ }^{1}$ The Clinical Nutrition Unit, Department of Clinical Sciences in Malmö, Diabetes and Cardiovascular Disease, Genetic Epidemiology, Lund University, Lund, Sweden

${ }^{5}$ Clinical Research Centre, Building 91:12, SUS in Malmö, Jan Waldenströms gata 35, 20502 Malmö, Sweden

Full list of author information is available at the end of the article
}

Submit your next manuscript to BioMed Central and we will help you at every step:

- We accept pre-submission inquiries

- Our selector tool helps you to find the most relevant journal

- We provide round the clock customer support

- Convenient online submission

- Thorough peer review

- Inclusion in PubMed and all major indexing services

- Maximum visibility for your research

Submit your manuscript at www.biomedcentral.com/submit
Biomed Central 